\title{
Amyloid-Beta Peptides Trigger Aggregation of Alpha-Synuclein In Vitro
}

\author{
Janett Köppen ${ }^{1, \dagger}$, Anja Schulze ${ }^{1, t, *}$, Lisa Machner ${ }^{1}$, Michael Wermann ${ }^{1}$, Rico Eichentopf ${ }^{1}$, \\ Max Guthardt ${ }^{2}$, Angelika Hähnel ${ }^{3}$, Jessica Klehm ${ }^{3}$, Marie-Christin Kriegeskorte ${ }^{4}$, \\ Maike Hartlage-Rübsamen ${ }^{4}$, Markus Morawski ${ }^{4}$, Stephan von Hörsten ${ }^{5}$ (D), \\ Hans-Ulrich Demuth ${ }^{1}$, Steffen Roßner ${ }^{4}$ and Stephan Schilling ${ }^{1}$ \\ 1 Fraunhofer Institute of Cell Therapy and Immunology, Department of Drug Design and Target Validation \\ IZI-MWT, 06120 Halle, Germany; janett.koeppen@izi.fraunhofer.de (J.K.); lisa.machner@uk-halle.de (L.M.); \\ michael.wermann@izi.fraunhofer.de (M.W.); rico.eichentopf@cbp.fraunhofer.de (R.E.); \\ hans-ulrich.demuth@izi.fraunhofer.de (H.-U.D.); stephan.schilling@izi.fraunhofer.de (S.S.) \\ 2 Fraunhofer Institute of Cell Therapy and Immunology IZI, 04103 Leipzig, Germany; \\ max.guthardt@izi.fraunhofer.de \\ 3 Fraunhofer Institute for Microstructure of Materials and Systems IMWS, 06120 Halle, Germany; \\ angelika.haehnel@imws.fraunhofer.de (A.H.); jessica.klehm@imws.fraunhofer.de (J.K.) \\ 4 Paul Flechsig Institute of Brain Research, University of Leipzig, 04109 Leipzig, Germany; \\ Marie-Christin.Kriegeskorte@medizin.uni-leipzig.de (M.-C.K.); maikerbs@uni-leipzig.de (M.H.-R.); \\ markus.morawski@medizin.uni-leipzig.de (M.M.); steffen.rossner@medizin.uni-leipzig.de (S.R.) \\ 5 Friedrich-Alexander-University Erlangen-Nürnberg, Preclinical Experimental Center, 91054 Erlangen, \\ Germany; stephan.v.hoersten@uk-erlangen.de \\ * Correspondence: anja.schulze@izi.fraunhofer.de; Tel.: +49-345-131428-07 \\ + These authors contributed equally to this work.
}

Academic Editor: Botond Penke

Received: 23 December 2019; Accepted: 28 January 2020; Published: 29 January 2020

check for updates

Abstract: Alzheimer's disease (AD) and Parkinson's disease (PD), including dementia with Lewy bodies (DLB), account for the majority of dementia cases worldwide. Interestingly, a significant number of patients have clinical and neuropathological features of both AD and PD, i.e., the presence of amyloid deposits and Lewy bodies in the neocortex. The identification of $\alpha$-synuclein peptides in amyloid plaques in DLB brain led to the hypothesis that both peptides mutually interact with each other to facilitate neurodegeneration. In this article, we report the influence of $A \beta(1-42)$ and pGlu-A $\beta(3-42)$ on the aggregation of $\alpha$-synuclein in vitro. The aggregation of human recombinant $\alpha$-synuclein was investigated using thioflavin-T fluorescence assay. Fibrils were investigated by means of antibody conjugated immunogold followed by transmission electron microscopy (TEM). Our data demonstrate a significantly increased aggregation propensity of $\alpha$-synuclein in the presence of minor concentrations of $A \beta(1-42)$ and pGlu-A $\beta(3-42)$ for the first time, but without effect on toxicity on mouse primary neurons. The analysis of the composition of the fibrils by TEM combined with immunogold labeling of the peptides revealed an interaction of $\alpha$-synuclein and $A \beta$ in vitro, leading to an accelerated fibril formation. The analysis of kinetic data suggests that significantly enhanced nucleus formation accounts for this effect. Additionally, co-occurrence of $\alpha$-synuclein and $\mathrm{A} \beta$ and pGlu-A $\beta$, respectively, under pathological conditions was confirmed in vivo by double immunofluorescent labelings in brains of aged transgenic mice with amyloid pathology. These observations imply a cross-talk of the amyloid peptides $\alpha$-synuclein and $\mathrm{A} \beta$ species in neurodegeneration. Such effects might be responsible for the co-occurrence of Lewy bodies and plaques in many dementia cases.

Keywords: alpha-synuclein ( $\alpha$-synuclein); Alzheimer's disease; amyloid-beta (A $\beta)$; dementia with Lewy bodies; Parkinson's disease 


\section{Introduction}

Parkinson's disease (PD) affects 10 million people worldwide and thus represents the second most frequent progressive neurodegenerative disorder, surpassed only by Alzheimer's disease (AD) [1]. The fibril formation of amyloidogenic proteins is a characteristic feature of both diseases, leading to progressive neuronal death [2].

Interestingly, the pathological characteristics of AD and PD show intriguing overlap, e.g., in addition to the typical Lewy bodies, PD patients often display amyloid plaques, a characteristic feature of $\mathrm{AD}$ [3]. On the other hand, Lewy bodies have been observed in $32-57 \%$ of sporadic $\mathrm{AD}$ cases $[4,5]$. Biochemical analysis showed that these deposits mainly consist of aggregated $\alpha$-synuclein [6]. Furthermore, the aggregation behavior of $\alpha$-synuclein underlays the same mechanism as $\mathrm{A} \beta$, describing a sigmoidal kinetic curve as a consequence of primary nucleation [7]. In addition to this process, secondary nucleation is also possible through the combination of both monomers and preformed fibrils $[8,9]$.

$\alpha$-synuclein is ubiquitously expressed in several tissues of the human body with the highest expression level in the central nervous system, where it is especially enriched in pre-synaptic nerve terminals [10]. Although $\alpha$-synuclein belongs to the group of intrinsically disordered proteins, the soluble peptide has the ability to adopt different conformations, which lead to a multitude of cytosolic, membrane-bound and aggregated states while interacting with ligands or proteins [11,12]. It is proposed that aggregates of $\alpha$-synuclein can promote misfolding and aggregation of other proteins through cross-seeding, which might be associated with the co-occurrence of multiple neurodegenerative diseases $[13,14]$. In addition, many post-translational protein modifications, e.g., phosphorylation at S129 of $\alpha$-synuclein, may also lead to altered aggregation behavior [15]. Mutation studies have shown that the region crucial for toxicity is the non-A $\beta$-component (NAC) domain, which was also found in the amino acid sequence of $A \beta$ deposits [16]. As shown in circular dichroism spectroscopy studies, this central sequence (aa 61-95) is essential for the formation of $\beta$-sheets of $\alpha$-synuclein [12,17-23]. The NAC region of $\alpha$-synuclein was found in $\mathrm{A} \beta$ deposits in AD patients, causing dementia with Lewy body (DLB) disease, and both peptides interact with each other through this region [24]. In addition, co-aggregation studies confirmed the mutual influence of the aggregation of $\mathrm{A} \beta$ and $\alpha$-synuclein by stabilizing the formation of aggregates [25]. By means of nuclear magnetic resonance (NMR) spectroscopy, it was shown that $\alpha$-synuclein and $A \beta$ interact via the synaptic membrane and that rupture of the membrane causes $\alpha$-synuclein release into the extracellular space [26]. Finally, the interaction of $\mathrm{A} \beta$ with $\alpha$-synuclein causes conformational changes generating NAC fragments.

To elucidate potential cross-connections between AD and PD, we aim at investigating how different amyloidogenic peptides might influence each other to force aggregation and deposition and, eventually, neurodegeneration. New insights into the co-aggregation are also intended to generate a basis for the development of specific antibodies to label heterogeneous aggregates of amyloid peptides typical for different clinical entities. These could help us to gain further understanding of the underlying pathological mechanisms, leading to the development of new therapeutic and diagnostic tools.

\section{Results}

\subsection{Expression and Purification of $\alpha$-Synuclein Variants}

In order to investigate the influence of the commonly used $\mathrm{His}_{6}$-tag on the aggregation properties of $\alpha$-synuclein, two different expression strategies were implemented to isolate $\alpha$-synuclein containing either a His $_{6}$-tag or a cleavable glutathione S-transferase (GST)-tag. Tobacco Etch Virus (TEV) protease was used for cleavage of the fusion part, leaving a native $\mathrm{N}$-terminus. The resulting wt- $\alpha$-synuclein and the $\mathrm{His}_{6}$-tagged variant were used to analyze a possible influence of the tag on the aggregation properties. In a typical approach, we isolated $2 \mathrm{mg} / \mathrm{L}$ of $\mathrm{His}_{6}-\alpha$-synuclein and $40 \mathrm{mg} / \mathrm{L} \mathrm{GST-His}{ }_{6}-\alpha$-synuclein. After TEV cleavage of GST-His ${ }_{6}-\alpha$-synuclein, we obtained about $4 \mathrm{mg} / \mathrm{l} \mathrm{wt}$ - $\alpha$-synuclein protein. An analytical SDS-PAGE characterizing the purity of GST-His ${ }_{6}-\alpha$-synuclein before cleavage with 
TEV protease and purified tag-free $w t-\alpha$-synuclein is shown in Figure 1. The molecular mass of $\mathrm{wt}-\alpha$-synuclein on SDS-PAGE and the corresponding signal in Western blot analysis differs from the theoretical value of $14 \mathrm{kDa}$ due to low binding of SDS by the highly acidic C-terminal sequence of $\alpha$-synuclein [27]. An additional protein product of $\sim 32 \mathrm{kDa}$ of free GST-tag is visible in lane 1 due to unspecific cleavage by endogenous proteases.

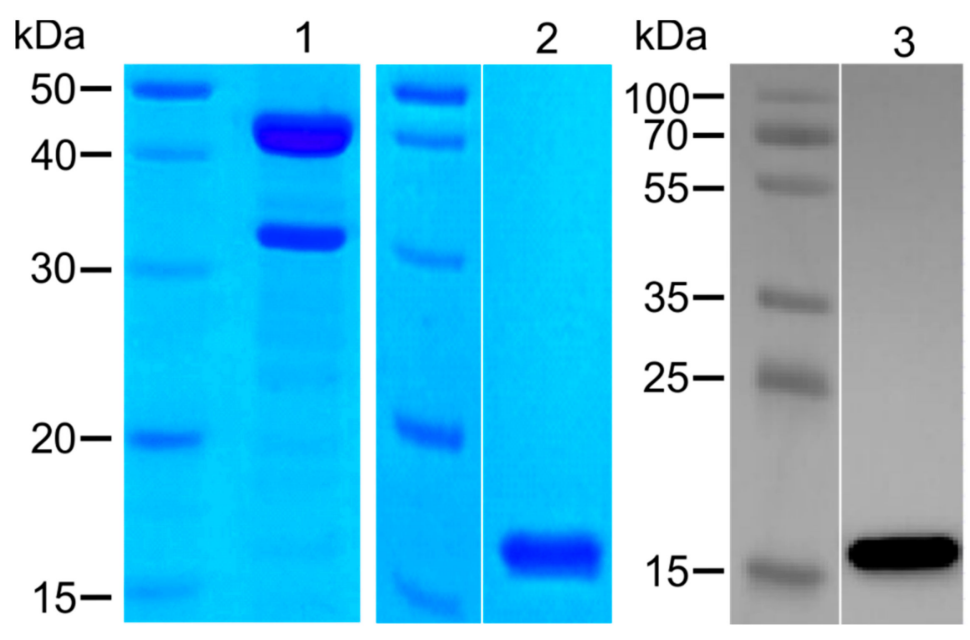

Figure 1. SDS-PAGE and Western blot analysis of $\alpha$-synuclein. GST-His ${ }_{6}-\alpha$-synuclein and wt- $\alpha$-synuclein were separated by denaturing SDS-PAGE and stained by Coomassie brilliant blue or by detection using MJFR-antibody (anti- $\alpha$-synuclein) in Western blot analysis. GST-His ${ }_{6}$ - $\alpha$-synuclein before cleavage (lane 1) migrated as a $\sim 42 \mathrm{kDa}$ monomer. After cleavage with TEV protease and a follow-up purification (lane 2 ), the resulting $\mathrm{wt}-\alpha$-synuclein showed a molecular mass of about $\sim 15 \mathrm{kDa}$, which was confirmed by protein-specific antibody (lane 3).

\subsection{Aggregation of $\mathrm{His}_{6}-\alpha$-Synuclein and $w \mathrm{t}-\alpha$-Synuclein}

To characterize the in vitro aggregation of $\mathrm{His}_{6}-\alpha$-synuclein and $\mathrm{wt}-\alpha$-synuclein at various concentrations, the ThT assay was performed. Fibril formation of both $\alpha$-synuclein peptides (Supplementary Figure S1) displayed a typical sigmoidal aggregation behavior [14,28] with decreasing lag phase at increasing $\alpha$-synuclein concentrations. Nevertheless, prominent discrepancies in aggregation velocity can be observed between the two $\alpha$-synuclein variants. For example, the nucleation of $\mathrm{His}_{6}-\alpha$-synuclein at $75 \mu \mathrm{M}$ required an average lag time of $111 \mathrm{~h}$ compared to $9 \mathrm{~h}$ lag time of wt- $\alpha$-synuclein at the same concentration (Figure 2 ). Thus, $\mathrm{His}_{6}-\alpha$-synuclein showed an approximately $92 \%$ longer lag phase than $\alpha$-synuclein with a native $\mathrm{N}$-terminus. In this regard, Huang et al. proved that kinetics of fibril formation of $\alpha$-synuclein are concentration-dependent, corroborating the results of our comparative studies [27]. 


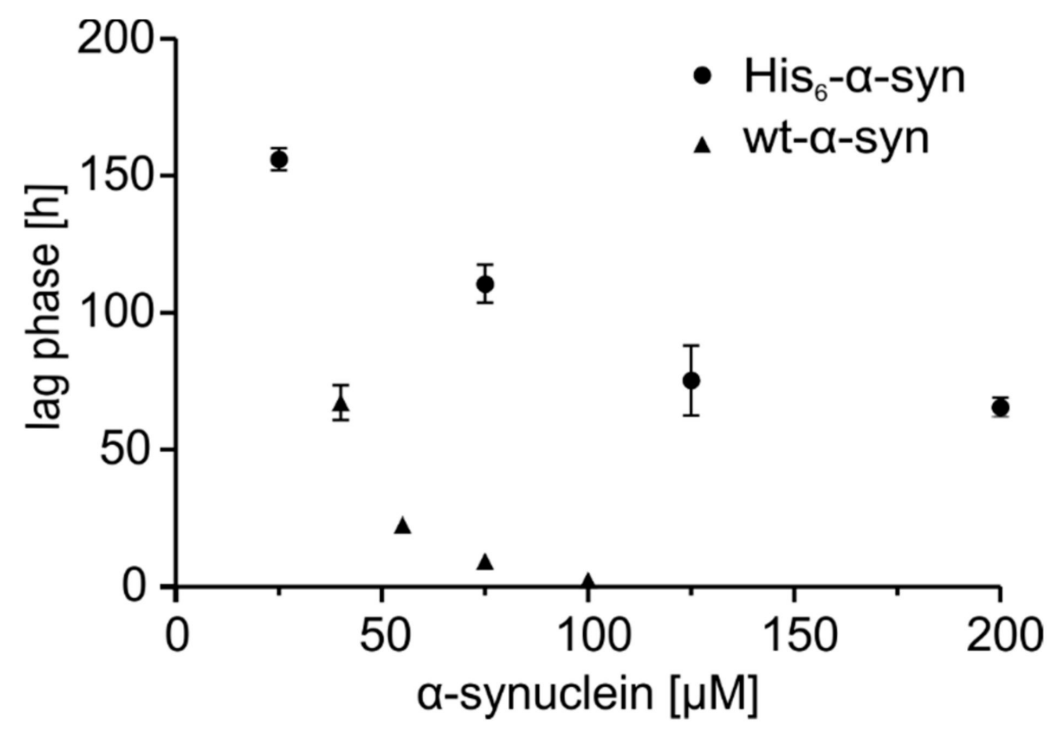

Figure 2. Comparison of lag phase duration obtained from aggregation kinetics of $\mathrm{His}_{6}$ - $\alpha$-synuclein (dots, $25 \mu \mathrm{M}, 75 \mu \mathrm{M}, 125 \mu \mathrm{M}, 200 \mu \mathrm{M}$ ) and wt- $\alpha$-synuclein (triangle, $40 \mu \mathrm{M}, 55 \mu \mathrm{M}, 75 \mu \mathrm{M}, 100 \mu \mathrm{M}$ ) measured by ThT fluorescence at pH $7.0(n=6)$.

\section{3. (Co)-aggregation of $\mathrm{His}_{6}-\alpha$-Synuclein and wt- $\alpha$-Synuclein with $A \beta(1-42)$ and $p G l u-A \beta(3-42)$}

To evaluate the effect of $A \beta(1-42)$ and pGlu-A $\beta(3-42)$ on the nucleation process, the $\alpha$-synuclein variants were analyzed in the presence of $\mathrm{A} \beta$ species at $\mathrm{pH}$ 7.0. The measurement of ThT binding to amyloid fibrils revealed that at the end of the growth phase and beginning of the steady-state phase, aggregation dynamics of preparations that solely contained $\alpha$-synuclein peptide variants differed significantly from $\alpha$-synuclein preparations after addition of $\mathrm{A} \beta$ species (Figure $3 \mathrm{~A}, \mathrm{~B}$ (left)). However, differences in ThT fluorescence intensity do not necessarily result from different fibril concentration, but could simply arise from two distinct ThT fibril binding modes [29]. Addition of either $A \beta$ species to each of the two $\alpha$-synuclein peptides had a significant effect on aggregation propensity (Figure 3A,B (right)). Intriguingly, lag phases of wt- $\alpha$-synuclein are $80 \%$ shorter in the presence of $\mathrm{A} \beta(1-42)$ and pGlu-A $\beta(3-42)$ (wt- $\alpha$-synuclein: $18 \mathrm{~h}, \mathrm{wt}-\alpha$-synuclein with $\mathrm{A} \beta(1-42)$ : $2 \mathrm{~h}$, wt- $\alpha$-synuclein with pGlu-A $\beta(3-42)$ : $4 \mathrm{~h}$ ). In contrast, aggregation kinetics of $\mathrm{His}_{6}-\alpha$-synuclein with the addition of $A \beta$ species only show lag phases shortened by about $50 \%$ ( $\mathrm{His}_{6}-\alpha$-synuclein: $87 \mathrm{~h}$, $\mathrm{His}_{6}$ - $\alpha$-synuclein with $A \beta(1-42): 42 \mathrm{~h}, \mathrm{His}_{6}-\alpha$-synuclein with pGlu-A $\beta(3-42)$ : $\left.35 \mathrm{~h}\right)$. However, the nature of the $A \beta$ species $A \beta(1-42)$ and pGlu-A $\beta(3-42)$, respectively, had no influence on the duration of the nucleation phase. Due to the impaired aggregation kinetics of $\mathrm{His}_{6}-\alpha$-synuclein, we focused the following experiments on $w \mathrm{t}-\alpha$-synuclein. 
A

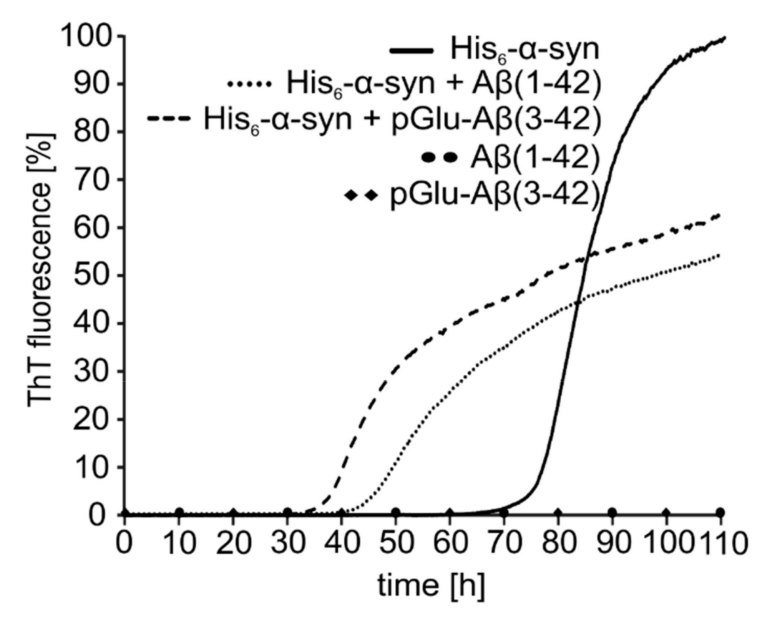

B

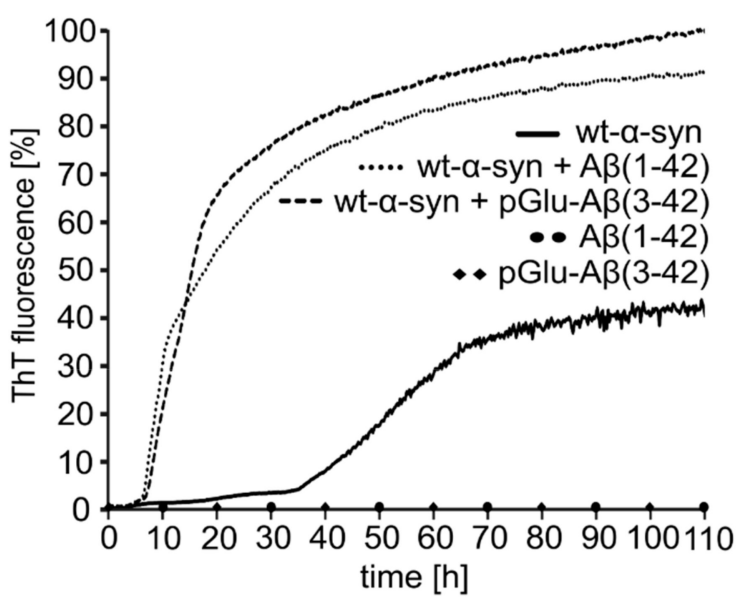

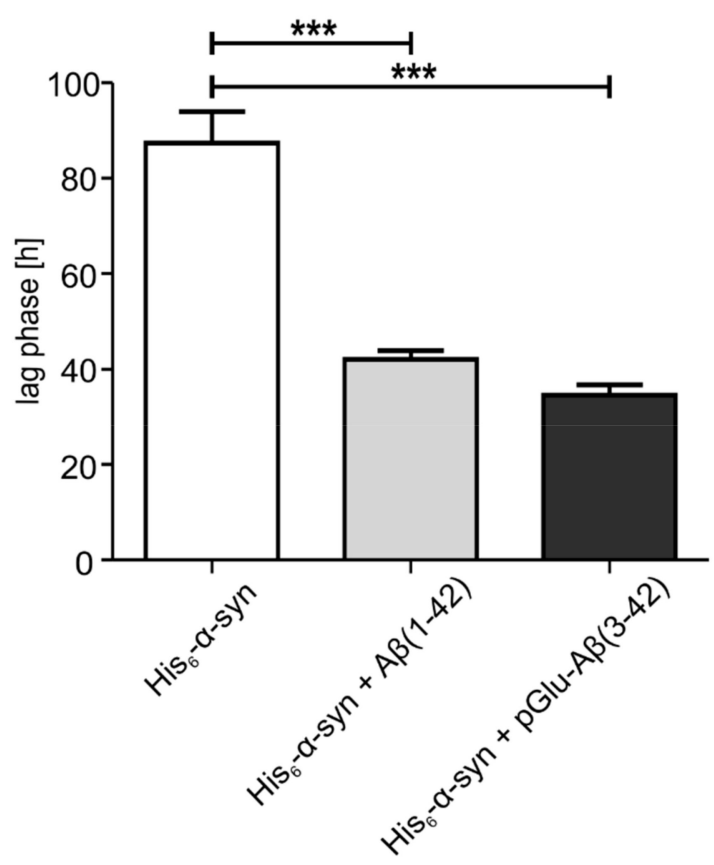
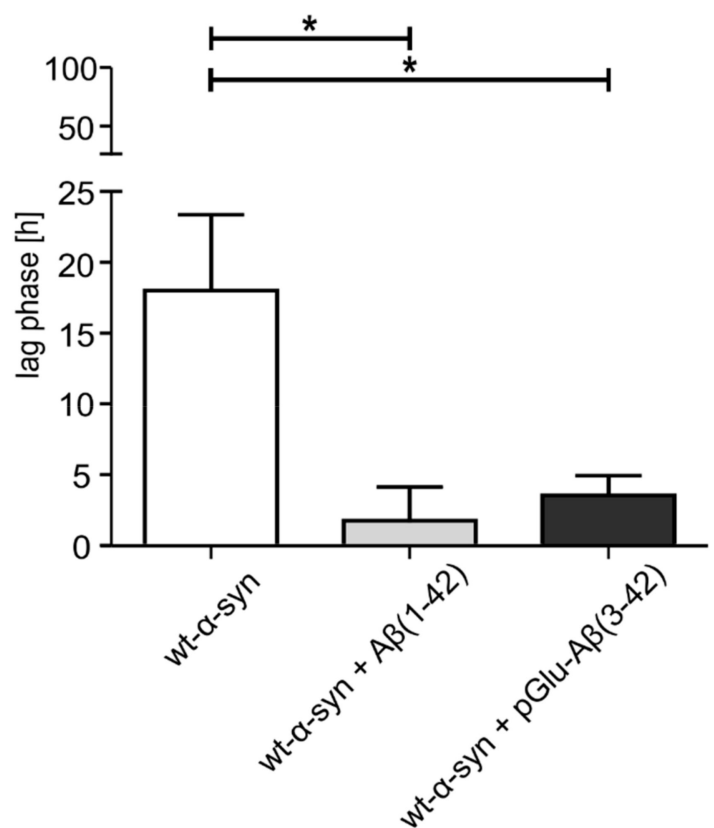

Figure 3. Kinetics of $\mathrm{His}_{6}-\alpha$-synuclein and $w \mathrm{t}-\alpha$-synuclein fibril formation and corresponding statistics of lag phase. Fibril formation was induced by incubation of either $\mathrm{His}_{6}-\alpha$-synuclein (A) or wt- $\alpha$-synuclein (B) assessed by ThT fluorescence at $\mathrm{pH}$ 7.0. Seventy-five micromolar of $\mathrm{His}_{6}$ - $\alpha$-synuclein or $55 \mu \mathrm{M} w \mathrm{t}-\alpha$-synuclein were either incubated alone (solid) or in combination with $1 \mu \mathrm{M} \mathrm{A} \beta(1-42)$ (dotted) or $1 \mu \mathrm{M}$ pGlu-A $\beta(3-42)$ (dashed). Fluorescence intensities of A $\beta$-peptides alone are visualized as dots. The corresponding statistical analysis of the lag phases was performed as described above (mean $\pm \mathrm{SD}, n=6,{ }^{*} p \leq 0.05$ and ${ }^{* *} p \leq 0.001$, one-way ANOVA and Tukey post-hoc analysis).

The co-aggregation of $\alpha$-synuclein with $A \beta(1-42)$ and pGlu-A $\beta(3-42)$ peptides in vitro was demonstrated by immunogold labeling of $\mathrm{A} \beta$ peptides ( $20 \mathrm{~nm}$ gold particle) and $\mathrm{wt}-\alpha$-synuclein aggregates ( $5 \mathrm{~nm}$ gold particles, Figure $4 \mathrm{~A}$ ). Furthermore, double immunofluorescent labelings with specific antibodies directed against the respective $A \beta$ peptides as well as $\alpha$-synuclein demonstrated co-occurrence in brains of APP-transgenic mice in vivo (Figure 4B). While $\alpha$-synuclein does not aggregate in wild type mouse brain (not shown), the marked and spatially restricted deposition of 
$\alpha$-synuclein around amyloid plaques in Tg2576 mouse brain supports in vitro data on A $\beta / \alpha$-synuclein protein co-aggregation. This co-labeling pattern was consistently detected irrespective of the brain region with amyloid plaques (hippocampus and neocortex) and of plaque size. For double immunohistochemical labelings in brain sections described above, control experiments in the absence of primary antibodies were carried out. In each case, this resulted in unstained brain sections (not shown). In addition, switching the fluorescent labels of the secondary antibodies (i.e., detection of $\alpha$-synuclein by secondary donkey anti-rabbit-Cy2 and visualization of $A \beta$ by donkey anti-mouse-Cy3) generated similar results as the procedure outlined above (not shown).

A
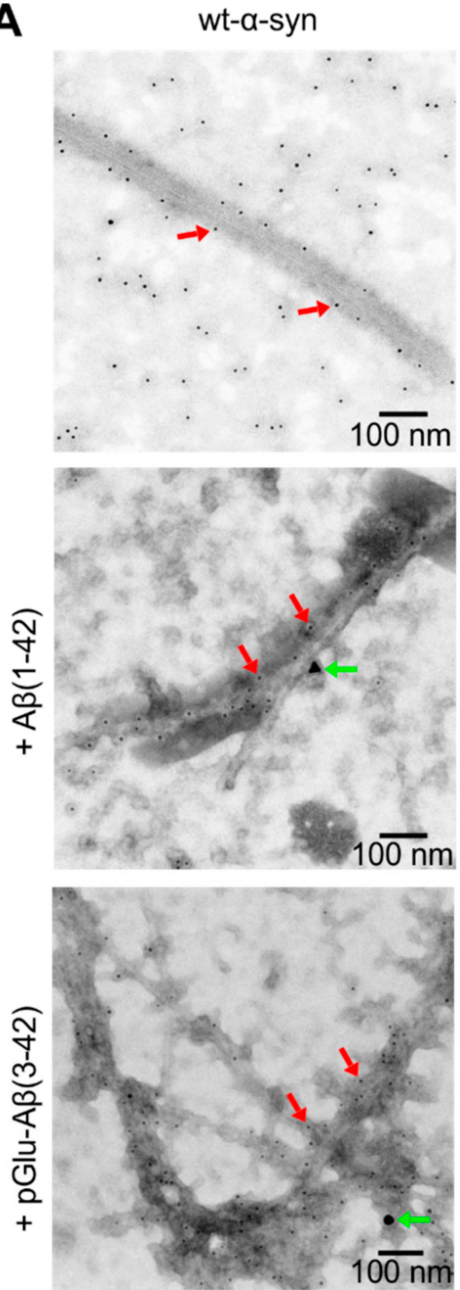

B
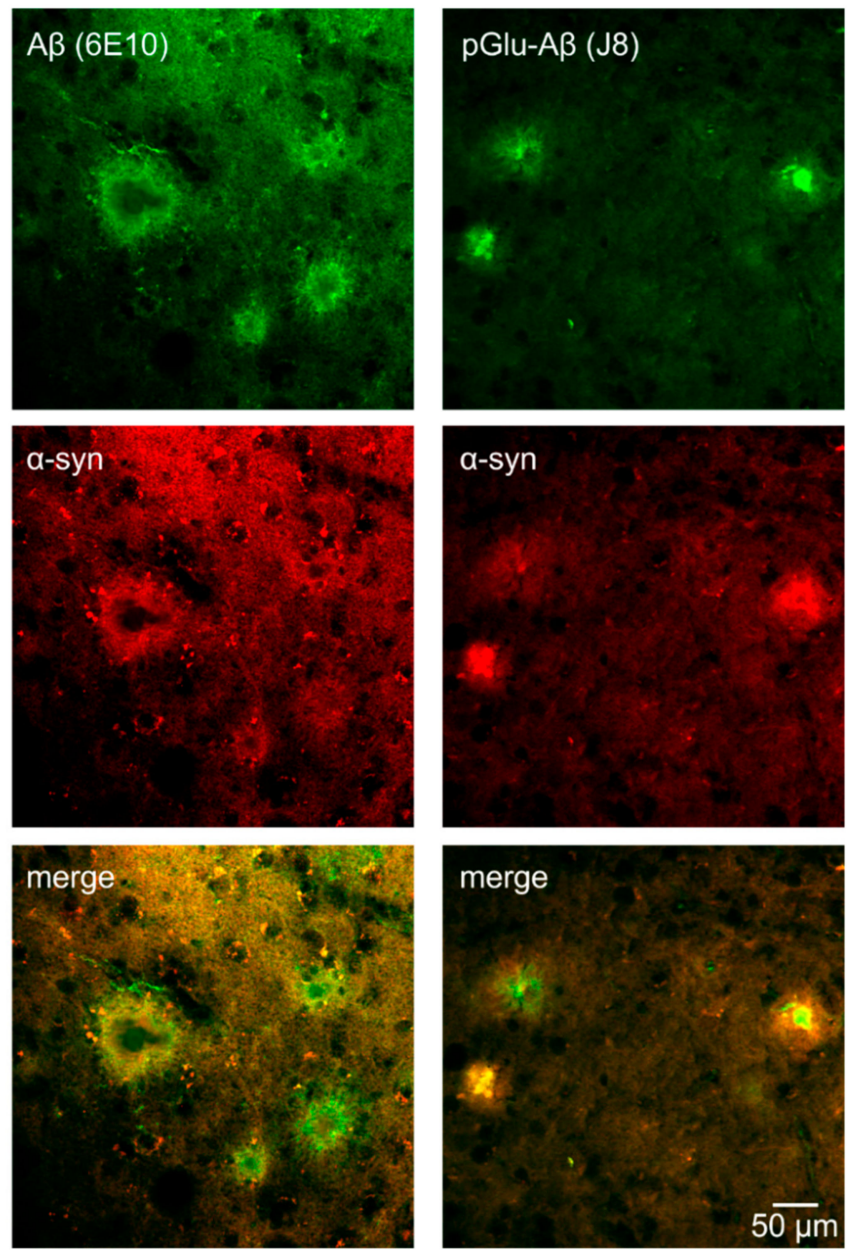

Figure 4. Co-aggregation of wt- $\alpha$-synuclein with $A \beta(1-42)$ and pGlu-A $\beta(3-42)$ in vitro and in vivo. (A) TEM images of amyloid fibrils of $w \mathrm{t}-\alpha$-synuclein alone (top) or in combination with $\mathrm{A} \beta(1-42)$ (middle) or pGlu-A $\beta(3-42)$ (bottom). Fibrils were labeled with immunogold particles of defined sizes to identify the different peptides: $5 \mathrm{~nm}$ gold particles for the $\alpha$-synuclein peptides (red arrows) and $20 \mathrm{~nm}$ gold particles for the $\mathrm{A} \beta$ peptides (green arrows). (B) Double immunofluorescent labeling of $\mathrm{A} \beta$ (green) and $\alpha$-synuclein (red) in the parietal cortex of $\operatorname{Tg} 2576$ mouse brain. The respective peptides were labeled with mouse monoclonal antibody $6 \mathrm{E} 10$ directed against the amino terminus of the A $\beta$ peptide, the pGlu-A $\beta$-specific mouse monoclonal antibody J8, and the rabbit anti-phospho-Serin129- $\alpha$-synuclein antibody ab51253, specific for aggregated $\alpha$-synuclein.

Comparative investigations on the fibril morphologies were performed by TEM. Electron micrographs of stained fibrils indicate the occurrence of different morphologies of wt- $\alpha$-synuclein fibrils alone and in presence of $A \beta(1-42)$ or pGlu-A $\beta(3-42)$ (Figure 5A). While fibrils of $w \mathrm{t}-\alpha$-synuclein appeared as evenly distributed short, protofibril-like structures, samples from 
aggregation reactions of wt- $\alpha$-synuclein with $\mathrm{A} \beta$ peptides exhibit networks of long, mature, and branched fibrils. To quantitatively analyze the morphological features of the fibrils, the distribution of fibril width was measured (Figure 5B). The incidence of thinner fibrils is increased for wt- $\alpha$-synuclein compared to fibrils nucleated by the $\mathrm{A} \beta$ species, which show a higher abundance of thicker fibrils. This observation is also reflected by the mean values of fibril diameter of around 10 and $12 \mathrm{~nm}$ for wt- $\alpha$-synuclein and wt- $\alpha$-synuclein with $\mathrm{A} \beta$ peptides, respectively. Statistical analyses of fibril diameters reveal significant differences between fibrils of wt- $\alpha$-synuclein alone and in the presence of A $\beta$ peptides (Figure $5 \mathrm{C}$ ).

A

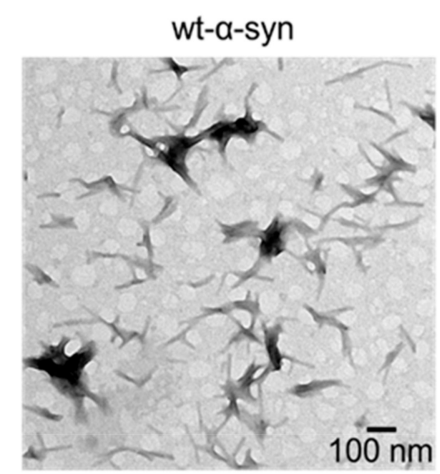

B

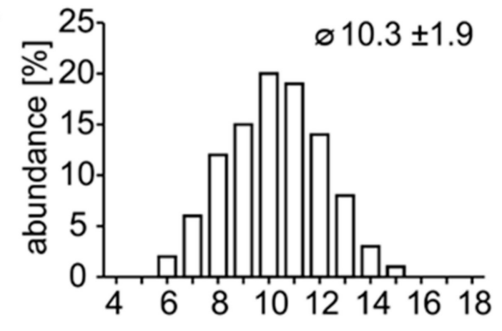

wt- $\alpha$-syn $+A \beta(1-42)$
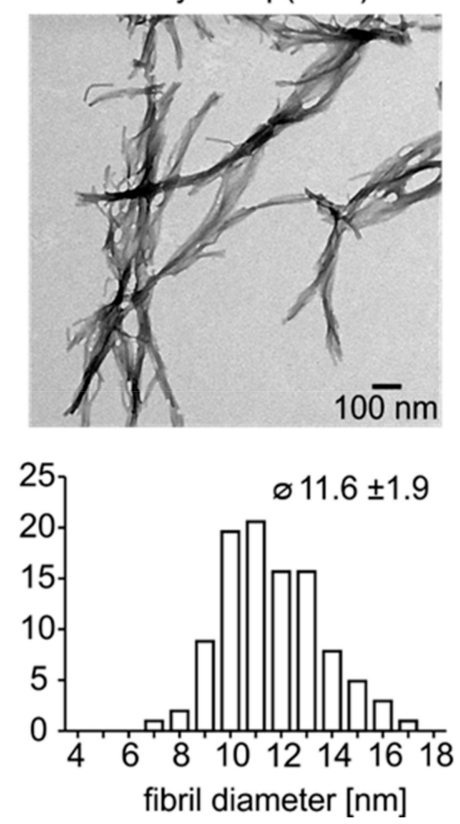

wt- $\alpha-s y n+$ pGlu-Aß(3-42)
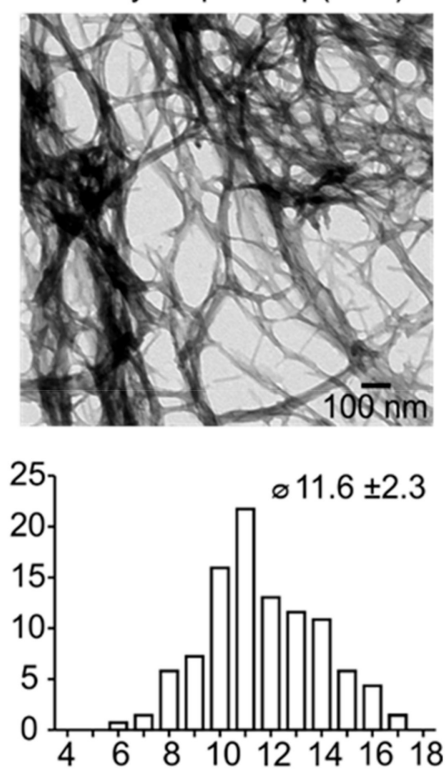

C

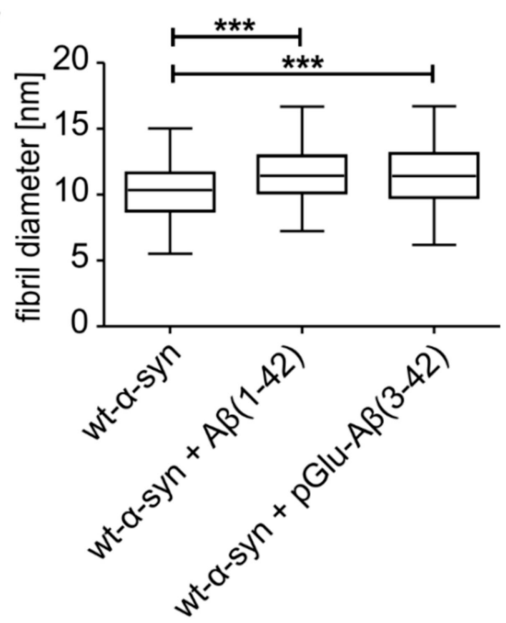

Figure 5. Analysis of amyloid fibrils formed from $w \mathrm{t}-\alpha$-synuclein $(75 \mu \mathrm{M})$ alone or in the presence of $\mathrm{A} \beta(1-42)$ or pGlu-A $\beta(3-42)(1 \mu \mathrm{M})$. (A) Negative stained TEM images and (B) corresponding histograms, mean value and standard deviation of fibril diameter quantifications from the above TEM images $(n=100)$. (C) Corresponding statistics of fibril diameter (mean $\pm \mathrm{SD}, n=100,{ }^{* * *} p \leq 0.001$, one-way ANOVA followed by Tukey post-hoc analysis). 


\subsection{Toxicity of Co-aggregates of wt- $\alpha$-Synuclein with $A \beta(1-42)$ and $p G l u-A \beta(3-42)$}

To study the toxicity of wt- $\alpha$-synuclein and co-aggregates of wt- $\alpha$-synuclein and $A \beta(1-42)$ or pGlu-A $\beta(3-42)$, an MTT assay was performed using primary neurons from whole mouse brains. The optimal $\alpha$-synuclein concentration was obtained from concentration-dependent kinetics of fibril formation of $\mathrm{wt}-\alpha$-synuclein at $20-100 \mu \mathrm{M}$ (Figure 2). No significant cytotoxic potential of $1 \mu \mathrm{M} \mathrm{A} \beta(1-42)$ or pGlu-A $\beta(3-42)$ was observed, which is in accordance with previous studies [30]. However, wt- $\alpha$-synuclein, as well as co-aggregates of wt- $\alpha$-synuclein and $\mathrm{A} \beta(1-42)$ or pGlu-A $\beta(3-42)$, reduced cell viability significantly at an average to $73 \%$ (wt- $\alpha$-synuclein: $75.8 \%$, wt- $\alpha$-synuclein with $\mathrm{A} \beta(1-42)$ : $72.5 \%$, wt- $\alpha$-synuclein with pGlu-A $\beta(3-42)$ : $70.9 \%$ ) of that of the vehicle control (Figure 6).

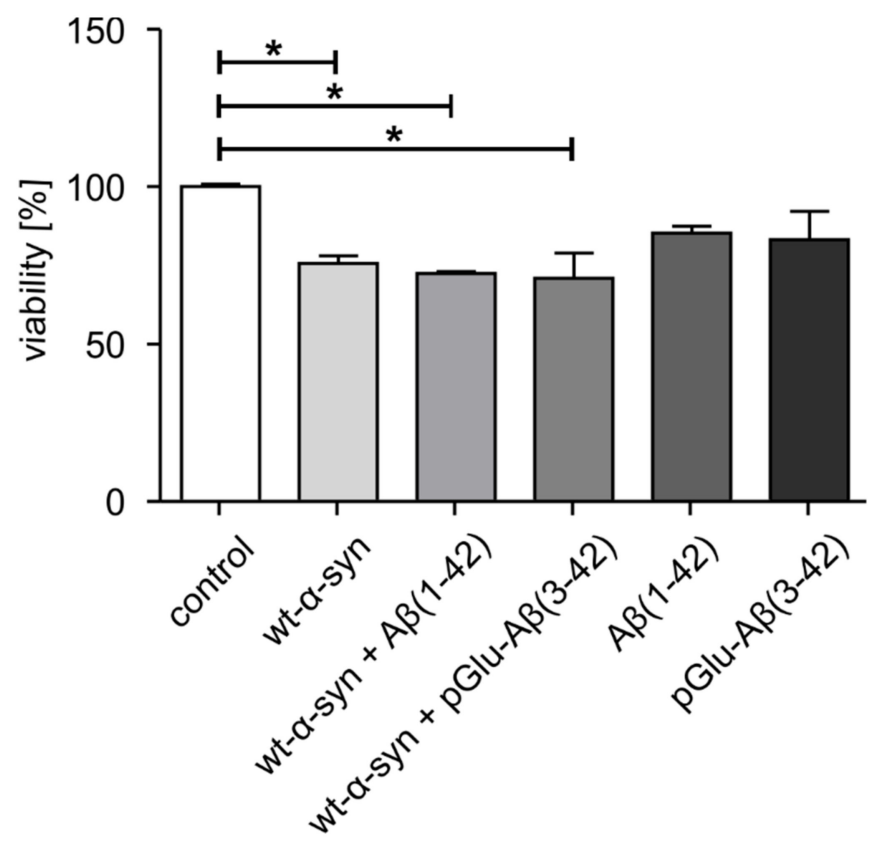

Figure 6. Analysis of cellular toxicity of aggregates of wt- $\alpha$-synuclein $(40 \mu \mathrm{M})$ in the presence or absence of $1 \mu \mathrm{M} \mathrm{A} \beta(1-42)$ or $1 \mu \mathrm{M}$ pGlu-A $\beta(3-42)$. Cell viability was assessed by MTT assay in mouse primary neurons after $72 \mathrm{~h}$ of treatment with the peptides (mean $\pm \mathrm{SD}, n=6,{ }^{*} p \leq 0.05$, one-way ANOVA followed by Tukey post-hoc analysis).

\section{Discussion}

$\alpha$-Synuclein has been identified as the causative protein in the pathogenesis of PD. One major neuropathological hallmark of the disease, besides the degeneration of dopaminergic neurons of the substantia nigra pars compacta, are the so-called Lewy bodies that contribute to the neurodegeneration. The triggers for the aggregation have not yet been determined with certainty, but it has been shown that various factors such as metal ions [31], oxidative substances [32], environmental factors, and genetic factors [33,34] can promote aggregation.

In addition to Lewy bodies, deposits of $A \beta$ peptides can be detected in PD brains [3], which implies a mutual influence of these peptides in their aggregation behavior.

\subsection{Acceleration of Fibril Formation of $\alpha$-Synuclein by $A \beta(1-42)$ and $p G l u-A \beta(3-42)$}

To characterize $\alpha$-synuclein aggregation, it was recombinantly expressed, purified, and analyzed in aggregation experiments. Subsequently, co-aggregation studies were performed in the presence of $\mathrm{A} \beta$ peptides. In addition to the already established construct $\mathrm{His}_{6}-\alpha$-synuclein, the GST- $\alpha$-synuclein was produced containing a cleavage site for the TEV protease to generate the native wt- $\alpha$-synuclein $\mathrm{N}$-terminus. 
Interestingly, comparative investigations of the aggregation kinetics of $\mathrm{His}_{6}-\alpha$-synuclein and $\mathrm{wt}-\alpha$-synuclein showed, for the first time, an adverse effect of the polyhistidine-tag on the aggregation efficiency. Although the lag phase decreased by increasing $\alpha$-synuclein concentrations with both peptide variants, the nucleation of untagged $\alpha$-synuclein proceeded much faster than that of $\mathrm{His}_{6}-\alpha$-synuclein. This effect implies that the length of the lag phase and the aggregation rate is not only dependent on factors such as protein concentration, $\mathrm{pH}$, temperature, and seeding [35-37], but also on minor modifications of the amino acid sequence. Thus, working with native recombinant peptides should be considered in future experiments. Similar observations were made in co-aggregation experiments. While aggregation kinetics of both $\alpha$-synuclein variants showed a sigmoidal, characteristic bipartite curve, the interaction of $\mathrm{His}_{6}-\alpha$-synuclein with $A \beta(1-42)$ or pGlu-A $\beta(3-42)$ appeared to be impaired by the $\mathrm{His}_{6}$-tag. However, co-aggregation with the $\mathrm{A} \beta$ peptides significantly reduced the lag time of both $\alpha$-synuclein variants, whereas the aggregation rate remained unaffected (Supplementary Figure S2). This result indicates that the $A \beta$ peptides accelerate the formation of heterogeneous fibrillation nuclei caused by additional nucleation seeds, while not increasing the efficiency of the polymerization process. Previous in vivo studies also demonstrated that the production of $\alpha$-synuclein oligomers and higher polymers are accelerated in the presence of $A \beta(1-42)$ compared to the aggregation of $\alpha$-synuclein alone $[25,38]$. Similar in vitro cross-seeding effects have been reported by Ono et al., where aggregates of $A \beta$ and $\alpha$-synuclein acted as seeds and promoted the aggregation of each other [39]. However, studies of Chia et al. show that in the presence of monomeric $\alpha$-synuclein, the secondary nucleation pathway is impeded, resulting in a decreased rate of the formation of $A \beta 42$ aggregates with limited effects on primary pathways [40]. Since $\alpha$-synuclein fibrils generated an opposite effect, they concluded that the influence of $\alpha$-synuclein on A $\beta 42$ aggregation depends strongly on the conformational state of $\alpha$-synuclein. Monomers of $\alpha$-synuclein possibly bind to A $\beta$ fibrils, thereby suppressing surface-catalyzed secondary nucleation [40].

Since lag phases of $\alpha$-synuclein are reduced in the presence of $A \beta$ species, we conclude that the primary nucleation pathway is accelerated. We could not observe a significant impact on the aggregation rate (Supplementary Figure S2). Additional experiments with preformed $\alpha$-synuclein fibrils would be needed to clear a possible inhibition of the secondary pathway.

The $\alpha$-synuclein/A $\beta$ co-aggregate formation was visualized by TEM. The immunogold labeling of the in vitro formed fibrils indicated that both $\alpha$-synuclein and the $\mathrm{A} \beta$ peptides are heterogeneously assembled co-aggregates. From the images, it is not clear whether the A $\beta$ peptides form seed nuclei in which both $\alpha$-synuclein monomers and $\alpha$-synuclein filaments attach, or whether the A $\beta$ peptides participate passively in the aggregation process of $\alpha$-synuclein, e.g., through increased oxidative stress [25]. However, protein aggregation may be promoted by synergistic cross-amyloid interactions of monomeric/oligomeric/fibrillar $\mathrm{A} \beta$ and $\alpha$-synuclein driven by hydrophobic amino acids [41]. It is postulated that $\alpha$-synuclein and $\mathrm{A} \beta$ peptides form complexes mediated by direct fibrillogenic interactions between these peptides probably via the highly hydrophobic NAC region of $\alpha$-synuclein and the hydrophobic regions around residues $16-21$ and $29-35$ of A $\beta[18,24,26,41]$. a similar coexistence has been reported for tau and $\alpha$-synuclein, i.e., abnormal tau aggregates accumulate in numerous cases of $\alpha$-synuclein deposition and vice versa [42-44]. This co-localization indicates a strong interaction between tauopathies and synucleinopathies, which is in strong support of a cross-seeding of pathogenic proteins $[43,45,46]$. This mutual influence on protein folding contributes to the progression of the disease disrupting cytoskeletal organization, impairing axonal transport, and compromising synaptic organization [38,46-54].

The co-appearance of $\alpha$-synuclein and $A \beta$ was further corroborated by double immunofluorescent labelings of the respective $\mathrm{A} \beta$ peptides with $\alpha$-synuclein in brains of transgenic mice with amyloid pathology in vivo. The pronounced and concentrated deposition of $\alpha$-synuclein around amyloid plaques supports in vitro data on $A \beta / \alpha$-synuclein protein co-aggregation. Interestingly, we have recently demonstrated that endogenous mouse huntingtin also co-aggregates to $A \beta$ plaques in Tg2576 mouse cortex and hippocampus [55]. From a more general perspective, this is consistent 
with the co-aggregation of proteins characteristic for different clinical entities (AD and PD, as well as AD and Huntington's disease) suggesting cross-disease mechanisms of pathogenic protein co-aggregation events.

The aggregation of $\alpha$-synuclein may result in various products, including fibrils, soluble oligomers, or insoluble amorphous aggregates [56]. In the TEM images obtained in our study, mainly fibrillar structures with different morphology were detected. Nielsen et al. showed by various biophysical experiments that $\alpha$-synuclein fibrils tend to form networks and elongated attachments after setting the steady-state phase [57]. Thus, this phase is not exclusively subject to the dynamic balance between degradation and aggregation, but also causes morphological differences of the fibrils. This property of branching is especially observed in fibrils of wt- $\alpha$-synuclein in the presence of $A \beta(1-42)$ or pGlu-A $\beta(3-42)$. It is striking that fibrils increase in thickness and length after simultaneous incubation with $A \beta$ species, which could be also an indication of a changed fibril structure. Annamalai et al. demonstrated that these polymorphisms also affect $A \beta$ fibrils. They found that in vivo amyloid fibrils of one patient can vary considerably in their three-dimensional architecture, irrespective of amyloid type or source [58]. Polymorphic properties of the fibrils could already be determined from the ThT aggregation assay. When analyzing the aggregation curves, different maximum ThT fluorescence intensities were observed. These could give information about the heterogeneity in the fibril morphology. ThT binds between the $\beta$-strands of the aggregates. However, the emitted light may be shielded by the molecular assembly in its environment, or less ThT may be bound due to structural changes in the fibrils. This has already been shown for the A $\beta$ isoforms 1-40 and 1-42 [59].

\section{2. (Co)-aggregate-mediated Cellular Toxicity}

Finally, the toxicity of wt- $\alpha$-synuclein and co-aggregates thereof with $\mathrm{A} \beta(1-42)$ or pGlu-A $\beta(3-42)$ was studied by using primary neurons from whole mouse brains in an MTT assay. Although the results of the ThT assay showed that aggregation velocity is significantly increased in the presence of $A \beta(1-42)$ and pGlu-A $\beta(3-42)$, no increased toxicity was observed compared to treatment of cells with wt- $\alpha$-synuclein alone. These results suggest that $\mathrm{wt}-\alpha$-synuclein increases neurotoxicity caused by the accumulation of $\alpha$-synuclein aggregates. Toxicity strongly depends on the conformation of the peptide. Several studies have proven that oligomers and protofibrils, i.e., $\beta$-sheet rich structures of $A \beta$ formed during the growth phase, are the toxic species compared to monomers and samples collected during the lag phase $[60,61]$. The decisive factor for the cytotoxicity is, therefore, the range between the lag phase and steady-state phase of aggregation, which can be analyzed by determining the aggregation rate. Since the aggregation rate remained unaffected (Supplementary Figure S2), one could postulate that the co-aggregation of $\alpha$-synuclein with $A \beta$ does not affect the formation of oligomers and protofibrils but accelerates the nucleation process.

Nevertheless, Hoenen et al. postulated that monomers and dimers of $\alpha$-synuclein might correspond to an early stage of PD and faster progression of the pathology [62]. In fact, they confirmed recent work on the degree of $\alpha$-synuclein-mediated toxicity by Lashuel et al., with regard to the conformation of the protein [63]. These results are in accordance with the hypothesis that in early stages of PD, small diffusible $\alpha$-synuclein proteins activate microglia leading to an inflammatory state [64]. Thus, to elucidate the putative influence of $\mathrm{A} \beta$ on $\alpha$-synuclein cytotoxicity, investigation of microglial activation might provide additional insights.

\section{Materials and Methods}

\subsection{Cloning, Expression, and Purification of Human $\alpha$-Synuclein Variants}

Cloning of $\alpha$-synuclein was performed by applying standard cloning procedures using a human cDNA clone purchased from Centic Biotec (Heidelberg, Germany) [65]. The DNA sequence coding for $\alpha$-synuclein was cloned into a pET28a $(+)$ plasmid vector containing a polyhistidine-tag at the $\mathrm{N}$-terminus. The fusion protein $\mathrm{His}_{6}-\alpha$-synuclein was expressed in E. coli strain BL21 with $0.4 \mathrm{mM}$ 
isopropyl $\beta$-D-thiogalactosidase (IPTG) at $37^{\circ} \mathrm{C}$ for 4 hours. Cell disruption was done by osmotic shock [27]. The first purification step was carried out through $\mathrm{Ni}^{2+}$-chelating chromatography on Streamline Chelating resin (Streamline Chelating, GE Healthcare Life Sciences, Uppsala, Sweden) with $\mathrm{a} \mathrm{cv}=140 \mathrm{~mL}$. The fractions obtained were analyzed and subjected to reversed phase chromatography (Source 15 RPC, GE Healthcare Life Sciences, Uppsala, Sweden), followed by lyophilisation and anion exchange chromatography (MonoQ 5/50GL, GE Healthcare Life Sciences, Uppsala, Sweden). The final buffer used for the experiments was $20 \mathrm{mM}$ Tris/HCl, pH 7.0, containing $100 \mathrm{mM} \mathrm{NaCl}$. The purity of the samples was assessed by SDS-PAGE and mass spectrometry. Protein concentrations were determined using UV absorption at $280 \mathrm{~nm}$.

To obtain a native $N$-terminus, a second $\alpha$-synuclein variant (wild-type, $\mathrm{wt}-\alpha$-synuclein) was created. Therefore, the DNA sequence coding for $\alpha$-synuclein was cloned into a pGEX-4T-1 plasmid vector. The resulting fusion protein contains an $N$-terminal GST-tag, followed by a polyhistidine-tag. The fusion is separated from the $\alpha$-synuclein sequence by a TEV protease cleavage sequence. TEV protease was isolated as described by Cabrita et al. [66]. The fusion protein GST-His ${ }_{6}-\alpha$-synuclein was expressed in E. coli strain BL21 with $0.4 \mathrm{mM}$ IPTG at $21^{\circ} \mathrm{C}$ overnight. Cell disruption was done by sonification. a first purification step was carried out through $\mathrm{Ni}^{2+}$-chelating chromatography on Streamline Chelating resin (Streamline Chelating, GE Healthcare Life Sciences, Uppsala, Sweden) with $\mathrm{a} \mathrm{cv}=140 \mathrm{~mL}$. Fractions containing the expression construct were combined, and a second purification step was proceeded with via glutathione sepharose resin and a cv of $19 \mathrm{ml}$ (Glutathione Sepharose 4FF, GE Healthcare Life Sciences, Uppsala, Sweden). The removal of glutathione was achieved by dialysis against buffer containing $100 \mathrm{mM} \mathrm{NaCl}, 30 \mathrm{mM}$ Tris/HCl pH = 7.6, $0.1 \mathrm{mM}$ DTT, and a membrane with cut-off 6-8 kDa overnight. The TEV cleavage reaction was done at RT overnight, followed by a final purification step via reversed phase chromatography (Source 15 RPC, GE Healthcare Life Sciences, Uppsala, Sweden). Fractions of interest were lyophilized and stored at $-20^{\circ} \mathrm{C}$ until usage.

\subsection{Synthesis of Amyloid Peptides}

$A \beta(1-42)$ and pGlu-A $\beta(3-42)$ were synthesized by solid-phase synthesis and purified as described previously [67]. Structures and purities of $A \beta$ peptides were confirmed by mass spectrometry. Before usage, peptides were dissolved in HFIP (Sigma-Aldrich, St. Louis, MO, USA) overnight. The solvents were evaporated under a stream of nitrogen and dissolved in $0.2 \mathrm{M} \mathrm{NaOH}$, followed by buffer and finally titrated with $0.2 \mathrm{M} \mathrm{HCl}$. Recombinant $\mathrm{A} \beta$ peptides were obtained as described previously [68].

\subsection{ThT Fluorescence Assay}

The thioflavin T (ThT) assay was carried out essentially as described previously [69]. The assay was conducted in 96-well plates using a FluoStar Optima (BMG Labtech, Ortenberg, Germany) plate reader. The excitation and emission wavelengths were 440 and $490 \mathrm{~nm}$, respectively. For monitoring fibril formation of the $\alpha$-synuclein variants, $20 \mu \mathrm{M}$ ThT (Sigma-Aldrich, St. Louis, MO, USA) was added to the aggregation buffer $(20 \mathrm{mM}$ Tris/ $\mathrm{HCl}, 100 \mathrm{mM} \mathrm{NaCl}, \mathrm{pH} 7.0)$. Signals were recorded at $37^{\circ} \mathrm{C}$ under continuous shaking ( $300 \mathrm{rpm}$ ) with a time interval of $\sim 15 \mathrm{~min}$ between each recording. For tracking the co-aggregation process of the two $\alpha$-synuclein variants, $\mathrm{A} \beta(1-42)$ or pGlu-A $\beta(3-42)$ were added. To analyze the obtained aggregation curves, we followed the procedure of Hortschansky et al. [70]. Therefore, the lag time $\left(t_{\mathrm{lag}}\right)$ of the aggregation was determined by fitting the straight lines $a$ to the baseline of the lag phase and $b$ as a tangent to the steepest region of the growth phase curve. $t_{\text {lag }}$ is defined as the time point where the two lines $a$ and $b$ intersect.

For each peptide, measurements were performed in six cavities of one plate. Obtained data were analyzed using one-way ANOVA, followed by Tukey post-hoc analysis. 


\subsection{Transmission Electron Microscopy and Immunogold Labelling}

Fibril samples $(5 \mu \mathrm{L})$ from an aggregation reaction as described above but without the use of ThT were directly incubated on a formvar carbon-coated copper grid (Plano, Wetzlar, Germany) for $10 \mathrm{~min}$ and washed three times with distilled water. Staining was obtained with $2 \%(v / v)$ uranyl acetate (SERVA Electrophoresis GmbH, Heidelberg, Germany) for $5 \mathrm{~min}$. Fibrils were imaged with a LEO EM 912 Omega TEM (Zeiss, Oberkochen, Germany) at $80 \mathrm{kV}$, and digital micrographs were obtained with a dual-speed 2K-on-axis CCD camera-based YAG scintillator (TRS-Tröndle, Moorenweis, Germany).

For immunogold labeling, the fibril samples were fixed on the grids with $2 \%(w / v)$ paraformaldehyde (Merck, Darmstadt, Germany) in PBS buffer (Thermo Fisher, Waltham, MA, USA) for 20 min followed by washing with distilled water. The sections were next incubated for $30 \mathrm{~min}$ at RT with blocking solution (1\% (w/v) BSA (Bovine Serum Album, Sigma-Aldrich) containing 0.1\% Tween-20 (Carl Roth, Karlsruhe, Germany) in PBS). After blocking, the grids were incubated with the first antibody overnight. Depending on the protein, the following antibodies were used: anti-alpha-synuclein filament antibody (rabbit monoclonal, recognizes $\alpha$-synuclein, MJFR-14-6-4-2, Abcam, Cambridge, UK), 6E10 (mouse monoclonal, recognizes A $\beta(1-42)$, Merck, Darmstadt, Germany) and ME8 (mouse monoclonal, recognizes pGlu-A $\beta(3-42)$, in-house). All primary antibodies were diluted 1:250 in blocking solution. After additional washing with blocking solution, the grids were incubated for $90 \mathrm{~min}$ with secondary antibodies coupled to colloidal gold: anti-rabbit IgG $5 \mathrm{~nm}$ gold (goat polyclonal, Sigma-Aldrich, St. Louis, MO, USA) and anti-mouse IgG $20 \mathrm{~nm}$ gold (goat polyclonal, Abcam, Berlin, Germany), diluted 1:50 in blocking solution. After three washing steps with distilled water, the grids were stained with $2 \%(v / v)$ phosphotungstic acid (Sigma-Aldrich, St. Louis, MO, USA) for $5 \mathrm{~min}$. The imaging of the fibril samples was performed by the use of a TEM/STEM FEI-TecnaiG2 F20 (Hillsboro, OR, USA) in STEM-mode at $200 \mathrm{kV}$. The electron micrographs were detected using a high-angle annular dark-field detector and finally processed by contrast-inversion.

\subsection{APP-Transgenic Tg2576 Mice}

In this study, APP-transgenic Tg2576 mice developed and described earlier [71] were used as the model for amyloid pathology and to reveal a potential aggregation of $\alpha$-synuclein to amyloid plaques in vivo. The mice express hAPP695 with the Swedish double mutation (K670N, M671L) as transgene under control of a hamster prion protein promoter. Mice heterozygous for the transgene and wild type littermates are on a mixed C57BL/ $6 \times$ SJL background. Mice were housed in groups of 3-5 animals per cage and separated by sex, with ad libitum access to water and food with $12 \mathrm{~h}$ day/12 h night cycles at $23^{\circ} \mathrm{C}$. The cages contained red plastic houses (Tecniplast) and shredded paper flakes to allow nest building. At the age of six weeks, the transgenicity of the animals was tested by polymerase chain reaction of tail DNA, as described elsewhere [71]. Mice were studied at the age of 18 months. Age-matched non-transgenic littermates served as controls.

\subsection{Antibodies Against $A \beta(1-42), p G l u-A \beta(3-42)$ and $\alpha$-Synuclein}

To specifically detect $A \beta(1-42)$, pGlu-A $\beta(3-42)$ and $\alpha$-synuclein in Tg2576 mouse brain sections, we used the mouse monoclonal antibody 6E10 directed against the amino terminus of the $A \beta$ peptide (Millipore; 1:1,000), the pGlu-A $\beta$-specific mouse monoclonal antibody J8 ([72]; 1:100) and the rabbit monoclonal phospho-Serin129- $\alpha$-synuclein antibody ab51253 (Abcam, Berlin, Germany, 1:200), which marks aggregated proteins in synucleinopathies $[73,74]$ and can be used as a peripheral prodromal Parkinson's disease (PD) marker [75].

\subsection{Immunohistochemistry}

Tissue preparation. Mice were sacrificed by $\mathrm{CO}_{2}$ inhalation until death and transcardially perfused with phosphate-buffered saline ( $\mathrm{pH} 7.4$ ) followed by $4 \%$ buffered paraformaldehyde through the left cardiac ventricle. After perfusion fixation, the brain was removed from the skull and placed in the 
same fixative overnight at $4^{\circ} \mathrm{C}$. Following cryoprotection in $30 \%$ sucrose in $0.1 \mathrm{M}$ phosphate buffer for 3 days, coronal sections $(30 \mu \mathrm{m})$ were cut on a sliding microtome and collected in $0.1 \mathrm{M}$ phosphate buffer containing $0.025 \%$ sodium azide.

\subsection{Double Immunofluorescent Labellings}

Simultaneous immunohistochemical labeling of $\mathrm{A} \beta$ and $\alpha$-synuclein, as well as pGlu-A $\beta(3-42)$ and $\alpha$-synuclein, was performed in Tg2576 mouse brain sections using a cocktail of the respective mouse monoclonal $\mathrm{A} \beta$ antibodies in combination with the rabbit anti- $\alpha$-synuclein antibody. All sections were pre-treated with $60 \%$ methanol for $60 \mathrm{~min}$ and unspecific staining was blocked by treatment with TBS containing 5\% normal donkey serum and $0.3 \%$ Triton-X100 before incubating brain sections with the primary antibody-mix in 5\% normal donkey serum and $0.1 \%$ Triton-X100 for $24 \mathrm{~h}$ at $4{ }^{\circ} \mathrm{C}$. Thereafter, brain sections were washed and transferred to a cocktail of secondary antibodies, i.e., Cy2-conjugated donkey anti-mouse (Dianova, Hamburg, Germany, 1:400), Cy3-conjugated donkey anti-rabbit (Dianova, Hamburg, Germany, 1:400) IgGs in TBS containing 2\% BSA for 60 min at RT. Brain sections were then washed, mounted onto glass slides and coverslipped.

\subsection{Confocal Laser Scanning Microscopy}

Confocal laser scanning microscopy (LSM 880 fast Airyscan NLO, Zeiss, Jena, Germany) was performed to reveal co-localization of $A \beta(1-42)$ and of pGlu-A $\beta(3-42)$, respectively, with $\alpha$-synuclein. The Cy2-labelled $\mathrm{A} \beta / \mathrm{pGlu}-\mathrm{A} \beta$ (green fluorescence) was visualized by excitation at $488 \mathrm{~nm}$ and detection of emission at $510 \mathrm{~nm}$ using a low-range band pass (505-530 nm) and the Cy3-labelled $\alpha$-synuclein (red fluorescence) was visualized using excitation at $543 \mathrm{~nm}$ and emission at $570 \mathrm{~nm}$. Antibody specificity was confirmed by omitting primary antibodies. Photoshop CS2 (Adobe Systems, Mountain View, CA, USA) was used to process the images obtained by light and confocal laser scanning microscopy with minimal alterations to brightness, sharpness, color saturation, and contrast.

\subsection{Colorimetric MTT Assay}

The toxic effect of $w \mathrm{t}-\alpha$-synuclein alone and in combination with $\mathrm{A} \beta(1-42)$ or pGlu-A $\beta(3-42)$ on neurons was assessed using an MTT assay (Sigma-Aldrich, St. Louis, MO, USA). Mouse primary neurons were isolated from whole brains as described by Becker et al. [76], but the embryo brains were removed at E14. Additionally, the cells were triturated with the use of trypsin. On a 24-well plate, 250,000 cells/well were spread and cultured at $37^{\circ} \mathrm{C}$ in a humidified atmosphere containing $5 \%$ $\mathrm{CO}_{2}$. Prior to use, $40 \mu \mathrm{M}$ wt- $\alpha$-synuclein in combination with $1 \mu \mathrm{M} A \beta(1-42)$ or $1 \mu \mathrm{M}$ pGlu-A $\beta(3-42)$ were pre-incubated at $37{ }^{\circ} \mathrm{C}$ for $24 \mathrm{~h}$ using cell culture medium. The cultivated cells were then treated with these proteins for 48 hours. Afterwards, MTT (3-[4,5-dimethylthiazol-2-yl]-2,5-diphenyl tetrazolium bromide) was added to the cell medium and incubated for four to six hours. The addition of acidic isopropanol solubilized the insoluble formazan precipitates produced by MTT reduction. The absorbance was determined at $570 \mathrm{~nm}$ using a plate reader (Tecan Sunrise, Männedorf, Switzerland). The value directly correlates to the number of viable cells.

\section{Conclusions}

Taken together, these results show, for the first time, an increased aggregation velocity of $\alpha$-synuclein in the presence of $A \beta(1-42)$ as well as pGlu-A $\beta(3-42)$. Further analyses of the fibrils revealed an interaction of $\alpha$-synuclein and $A \beta$ in vitro and in vivo, resulting in an accelerated fibril formation most likely caused by an enhanced nucleus formation. These observations suggest a potential cross-talk of different amyloid peptide families such as $\alpha$-synuclein and A $\beta$ in amyloid-based neurodegenerative diseases. The present results of this study may provide the basis to develop new specific antibodies to label heterogeneous deposits of $\alpha$-synuclein and $A \beta$, enabling the development of novel therapeutic and diagnostic approaches. 
Supplementary Materials: The following figures are available online: Figure S1: Aggregation kinetics of His6- $\alpha$-synuclein and wt- $\alpha$-synuclein.; Figure S2: Evaluation of the aggregation rate k of His6- $\alpha$-synuclein and wt- $\alpha$-synuclein..

Author Contributions: Conceptualization, A.S., H.-U.D. and S.S.; methodology, J.K. (Janett Köppen), L.M., M.W., R.E., M.G., A.H., M.-C.K., M.H.-R. and M.M.; validation, A.S., J.Kl., S.R., S.v.H. and S.S.; investigation, A.S., J.Kö., L.M., A.H., M.-C.K., M.H.-R. and M.M.; resources, R.E., M.G., A.H., J.K. (Jessica Klehm) and M.M.; writing-original draft preparation, A.S. and J.K. (Janett Köppen); writing-review and editing, M.H.-R., M.M., S.R. and S.S.; visualization, J.K. (Janett Köppen) and A.S.; supervision, H.-U.D. and S.S.; funding acquisition, S.R., S.v.H. and H.-U.D. All authors have read and agreed to the published version of the manuscript.

Funding: Aspects of this work were supported by the German Federal Department of Education, Science, and Technology, BMBF (grant \#01ED1501A to HUD, grant \#01ED1501B to SR and grant \#01ED1501C to SvH) within the European Union Joint Program for Neurodegenerative Disease (JPND) Research, Project CrossSeeds.

Acknowledgments: The authors would like to thank the Fraunhofer-Gesellschaft for participating in the CBS project and Katrin Schulz and Mercedes Scharfe for expert technical assistance. We are grateful to Karen Hsiao-Ashe, University of Minnesota, for providing Tg2576 mouse breeding pairs.

Conflicts of Interest: The authors declare no conflict of interest.

\section{References}

1. Al-Busaidi, I.S.; Anderson, T.J.; Alamri, Y. Qualitative analysis of Parkinson's disease information on social media: The case of YouTube ${ }^{\mathrm{TM}}$. Epma J. 2017, 8, 273-277. [CrossRef] [PubMed]

2. Ross, C.A.; Poirier, M.A. Protein aggregation and neurodegenerative disease. Nat. Med. 2004, 10, S10-S17. [CrossRef]

3. Galpern, W.R.; Lang, A.E. Interface between tauopathies and synucleinopathies: a tale of two proteins. Ann. Neurol. 2006, 59. [CrossRef] [PubMed]

4. Hamilton, R.L. Lewy bodies in Alzheimer's disease: a neuropathological review of 145 cases using alpha-synuclein immunohistochemistry. Brain Pathol. 2000, 10, 378-384. [CrossRef] [PubMed]

5. Jellinger, K.A. Lewy body-related alpha-synucleinopathy in the aged human brain. J. Neural Transm. 2004, 111, 1219-1235. [CrossRef] [PubMed]

6. Arima, K.; Hirai, S.; Sunohara, N.; Aoto, K.; Izumiyama, Y.; Uéda, K.; Ikeda, K.; Kawai, M. Cellular co-localization of phosphorylated tau- and NACP/ alpha-synuclein-epitopes in Lewy bodies in sporadic Parkinson's disease and in dementia with Lewy bodies. Brain Res. 1999, 843, 53-61. [CrossRef]

7. Knowles, T.P.J.; Vendruscolo, M.; Dobson, C.M. The amyloid state and its association with protein misfolding diseases. Nat. Rev. Mol. Cell Biol. 2014, 15, 384-396. [CrossRef]

8. Knowles, T.P.J.; Waudby, C.A.; Devlin, G.L.; Cohen, S.I.A.; Aguzzi, A.; Vendruscolo, M.; Terentjev, E.M.; Welland, M.E.; Dobson, C.M. An analytical solution to the kinetics of breakable filament assembly. Science 2009, 326, 1533-1537. [CrossRef]

9. Cohen, S.I.A.; Linse, S.; Luheshi, L.M.; Hellstrand, E.; White, D.A.; Rajah, L.; Otzen, D.E.; Vendruscolo, M.; Dobson, C.M.; Knowles, T.P.J. Proliferation of amyloid- $\beta 42$ aggregates occurs through a secondary nucleation mechanism. Proc. Natl. Acad. Sci. USA 2013, 110, 9758-9763. [CrossRef]

10. Iwai, A.; Masliah, E.; Yoshimoto, M.; Ge, N.; Flanagan, L.; Rohan de Silva, H.A.; Kittel, A.; Saitoh, T. The precursor protein of non-AB component of Alzheimer's disease amyloid is a presynaptic protein of the central nervous system. Neuron 1995, 14, 467-475. [CrossRef]

11. Li, J.; Uversky, V.N.; Fink, A.L. Effect of familial Parkinson's disease point mutations A30P and A53T on the structural properties, aggregation, and fibrillation of human alpha-synuclein. Biochemistry 2001, 40, 11604-11613. [CrossRef] [PubMed]

12. Fusco, G.; de Simone, A.; Gopinath, T.; Vostrikov, V.; Vendruscolo, M.; Dobson, C.M.; Veglia, G. Direct observation of the three regions in $\alpha$-synuclein that determine its membrane-bound behaviour. Nat. Commun. 2014, 5, 3827. [CrossRef] [PubMed]

13. Lim, K.H. Diverse misfolded conformational strains and cross-seeding of misfolded proteins implicated in neurodegenerative diseases. Front. Mol. Neurosci. 2019, 12, 158. [CrossRef] [PubMed]

14. Ke, P.C.; Sani, M.-A.; Ding, F.; Kakinen, A.; Javed, I.; Separovic, F.; Davis, T.P.; Mezzenga, R. Implications of peptide assemblies in amyloid diseases. Chem. Soc. Rev. 2017, 46, 6492-6531. [CrossRef] 
15. Sato, H.; Kato, T.; Arawaka, S. The role of Ser129 phosphorylation of $\backslash$ alpha-synuclein in neurodegeneration of Parkinson' s disease: a review of in vivo models. Neurosci 2012, 24, 115-123. [CrossRef]

16. Bodles, A.M.; Guthrie, D.J.S.; Greer, B.; Brent Irvine, G. Identification of the region of non-Abeta component (NAC) of Alzheimer's disease amyloid responsible for its aggregation and toxicity. J. Neurochem. 2001, 78, 384-395. [CrossRef]

17. Giasson, B.I.; Murray, I.V.J.; Trojanowski, J.Q.; Lee, V.M.Y. a hydrophobic stretch of 12 amino acid residues in the middle of alpha-synuclein is essential for filament assembly. J. Biol. Chem. 2001, 276, 2380-2386. [CrossRef]

18. El-Agnaf, O.M.A.; Irvine, G.B. Aggregation and neurotoxicity of \alpha-synuclein and related peptides. Biochem. Soc. Trans. 2002, 30, 559-565. [CrossRef]

19. Han, H.; Weinreb, P.H.; Lansbury, P.T. The core Alzheimer's peptide NAC forms amyloid fibrils which seed and are seeded by beta-amyloid: Is NAC a common trigger or target in neurodegenerative disease? Chem. Biol. 1995, 2, 163-169. [CrossRef]

20. Takeda, A.; Mallory, M.; Sundsmo, M.; Honer, W.; Hansen, L.; Masliah, E. Abnormal accumulation of NACP/alpha-synuclein in neurodegenerative disorders. Am. J. Pathol. 1998, 152, 367-372.

21. Uéda, K.; Fukushima, H.; Masliah, E.; Xia, Y.; Iwai, A.; Yoshimoto, M.; Otero, D.A.; Kondo, J.; Ihara, Y.; Saitoh, T. Molecular cloning of cDNA encoding an unrecognized component of amyloid in Alzheimer disease. Proc. Natl. Acad. Sci. 1993, 90, 11282-11286. [CrossRef] [PubMed]

22. Walker, Z.; Possin, K.L.; Boeve, B.F.; Aarsland, D. Lewy body dementias. Lancet 2015, 386, $1683-1697$. [CrossRef]

23. Stinton, C.; McKeith, I.; Taylor, J.-P.; Lafortune, L.; Mioshi, E.; Mak, E.; Cambridge, V.; Mason, J.; Thomas, A.; O'Brien, J.T. Pharmacological management of lewy body dementia: a systematic review and meta-analysis. Am. J. Psychiatry 2015, 172, 731-742. [CrossRef] [PubMed]

24. Yoshimoto, M.; Iwai, A.; Kang, D.; Otero, D.A.; Xia, Y.; Saitoh, T. NACP, the precursor protein of the non-amyloid beta/A4 protein (A beta) component of Alzheimer disease amyloid, binds a beta and stimulates a beta aggregation. Proc. Natl. Acad. Sci. 1995, 92, 9141-9145. [CrossRef]

25. Tsigelny, I.F.; Crews, L.; Desplats, P.; Shaked, G.M.; Sharikov, Y.; Mizuno, H.; Spencer, B.; Rockenstein, E.; Trejo, M.; Platoshyn, O.; et al. Mechanisms of hybrid oligomer formation in the pathogenesis of combined Alzheimer's and Parkinson's diseases. PLoS ONE 2008, 3. [CrossRef]

26. Mandal, P.K.; Pettegrew, J.W.; Masliah, E.; Hamilton, R.L.; Mandal, R. Interaction between Abeta peptide and alpha synuclein: Molecular mechanisms in overlapping pathology of Alzheimer's and Parkinson's in dementia with Lewy body disease. Neurochem. Res. 2006, 31, 1153-1162. [CrossRef]

27. Huang, C.; Ren, G.; Zhou, H.; Wang, C.-c. a new method for purification of recombinant human alpha-synuclein in Escherichia coli. Protein Expr. Purif. 2005, 42, 173-177. [CrossRef]

28. Finder, V.H.; Glockshuber, R. Amyloid-beta aggregation. Neurodegener. Dis. 2007, 4, 13-27. [CrossRef]

29. Gade Malmos, K.; Blancas-Mejia, L.M.; Weber, B.; Buchner, J.; Ramirez-Alvarado, M.; Naiki, H.; Otzen, D. ThT 101: a primer on the use of thioflavin T to investigate amyloid formation. Amyloid 2017, 24, 1-16. [CrossRef]

30. Nussbaum, J.M.; Schilling, S.; Cynis, H.; Silva, A.; Swanson, E.; Wangsanut, T.; Tayler, K.; Wiltgen, B.; Hatami, A.; Rönicke, R.; et al. Prion-like behaviour and tau-dependent cytotoxicity of pyroglutamylated amyloid- $\beta$. Nature 2012, 485, 651-655. [CrossRef]

31. Paik, S.R.; Shin, H.J.; Lee, J.H. Metal-catalyzed oxidation of alpha-synuclein in the presence of Copper(II) and hydrogen peroxide. Arch. Biochem. Biophys. 2000, 378, 269-277. [CrossRef] [PubMed]

32. Souza, J.M.; Giasson, B.I.; Chen, Q.; Lee, V.M.Y.; Ischiropoulos, H. Dityrosine cross-linking promotes formation of stable \alpha-synuclein polymers: Implication of nitrative and oxidative stress in the pathogenesis of neurodegenerative synucleinopathies. J. Biol. Chem. 2000, 275, 18344-18349. [CrossRef] [PubMed]

33. Olanow, C.W.; Tatton, W.G. Etiology and pathogenesis of Parkinson's disease. Annu. Rev. Neurosci. 1999, $22,123-144$. [CrossRef] [PubMed]

34. Uversky, V.N. Neuropathology, biochemistry, and biophysics of alpha-synuclein aggregation. J. Neurochem. 2007, 103, 17-37.

35. Bauer, H.H.; Aebi, U.; Häner, M.; Hermann, R.; Müller, M.; Merkle, H.P. Architecture and polymorphism of fibrillar supramolecular assemblies produced by in vitro aggregation of human calcitonin. J. Struct. Biol. 1995, 115, 1-15. [CrossRef]

36. Andersen, C.B.; Otzen, D.; Christiansen, G.; Rischel, C. Glucagon amyloid-like fibril morphology is selected via morphology-dependent growth inhibition. Biochemistry 2007, 46, 7314-7324. [CrossRef] 
37. Fink, A.L. Factors Affecting the Fibrillation of $\alpha$-Synuclein, a Natively Unfolded Protein. In Misbehaving Proteins: Protein (Mis)folding, Aggregation, and Stability; Murphy, R.M., Tsai, A.M., Eds.; Springer: New York, NY, USA, 2006; pp. 265-285. ISBN 978-0-387-30508-0.

38. Masliah, E.; Rockenstein, E.; Veinbergs, I.; Sagara, Y.; Mallory, M.; Hashimoto, M.; Mucke, L. beta-amyloid peptides enhance alpha-synuclein accumulation and neuronal deficits in a transgenic mouse model linking Alzheimer's disease and Parkinson's disease. Proc. Natl. Acad. Sci. USA 2001, 98, 12245-12250. [CrossRef]

39. Ono, K.; Takahashi, R.; Ikeda, T.; Yamada, M. Cross-seeding effects of amyloid $\beta$-protein and $\alpha$-synuclein. J. Neurochem. 2012, 122, 883-890. [CrossRef]

40. Chia, S.; Flagmeier, P.; Habchi, J.; Lattanzi, V.; Linse, S.; Dobson, C.M.; Knowles, T.P.J.; Vendruscolo, M. Monomeric and fibrillar $\alpha$-synuclein exert opposite effects on the catalytic cycle that promotes the proliferation of Aß42 aggregates. Proc. Natl. Acad. Sci. USA 2017, 114, 8005-8010. [CrossRef]

41. Luo, J.; Wärmländer, S.K.T.S.; Gräslund, A.; Abrahams, J.P. Cross-interactions between the Alzheimer disease amyloid- $\beta$ peptide and other amyloid proteins: a further aspect of the amyloid cascade hypothesis. J. Biol. Chem. 2016, 291, 16485-16493. [CrossRef]

42. Brion, J.P.; Couck, A.M.; Passareiro, E.; Flament-Durand, J. Neurofibrillary tangles of Alzheimer's disease: An immunohistochemical study. J. Submicrosc. Cytol. 1985, 17, 89-96. [PubMed]

43. Kosik, K.S.; Joachim, C.L.; Selkoe, D.J. Microtubule-associated protein tau (tau) is a major antigenic component of paired helical filaments in Alzheimer disease. Proc. Natl. Acad. Sci. USA 1986, 83, 4044-4048. [CrossRef] [PubMed]

44. Vasili, E.; Dominguez-Meijide, A.; Outeiro, T.F. Spreading of $\alpha$-synuclein and tau: a systematic comparison of the mechanisms involved. Front. Mol. Neurosci. 2019, 12, 107. [CrossRef] [PubMed]

45. Spillantini, M.G.; Schmidt, M.L.; Lee, V.M.; Trojanowski, J.Q.; Jakes, R.; Goedert, M. Alpha-synuclein in Lewy bodies. Nature 1997, 388, 839-840. [CrossRef]

46. Cabrales Fontela, Y.; Kadavath, H.; Biernat, J.; Riedel, D.; Mandelkow, E.; Zweckstetter, M. Multivalent cross-linking of actin filaments and microtubules through the microtubule-associated protein Tau. Nat. Commun. 2017, 8, 1981. [CrossRef]

47. Giasson, B.I.; Forman, M.S.; Higuchi, M.; Golbe, L.I.; Graves, C.L.; Kotzbauer, P.T.; Trojanowski, J.Q.; Lee, V.M.-Y. Initiation and synergistic fibrillization of tau and alpha-synuclein. Science 2003, 300, 636-640. [CrossRef]

48. Bellani, S.; Sousa, V.L.; Ronzitti, G.; Valtorta, F.; Meldolesi, J.; Chieregatti, E. The regulation of synaptic function by alpha-synuclein. Commun. Integr. Biol. 2010, 3, 106-109. [CrossRef]

49. Sotiropoulos, I.; Galas, M.-C.; Silva, J.M.; Skoulakis, E.; Wegmann, S.; Maina, M.B.; Blum, D.; Sayas, C.L.; Mandelkow, E.-M.; Mandelkow, E.; et al. Atypical, non-standard functions of the microtubule associated Tau protein. Acta Neuropathol. Commun. 2017, 5, 91. [CrossRef]

50. Biswas, S.; Kalil, K. The microtubule-associated protein tau mediates the organization of microtubules and their dynamic exploration of actin-rich lamellipodia and filopodia of cortical growth cones. J. Neurosci. Off. J. Soc. Neurosci. 2018, 38, 291-307. [CrossRef]

51. Ordonez, D.G.; Lee, M.K.; Feany, M.B. $\alpha$-Synuclein induces mitochondrial dysfunction through spectrin and the actin cytoskeleton. Neuron 2018, 97, 108-124.e6. [CrossRef]

52. Prots, I.; Grosch, J.; Brazdis, R.-M.; Simmnacher, K.; Veber, V.; Havlicek, S.; Hannappel, C.; Krach, F.; Krumbiegel, M.; Schütz, O.; et al. $\alpha$-Synuclein oligomers induce early axonal dysfunction in human iPSC-based models of synucleinopathies. Proc. Natl. Acad. Sci. USA 2018, 115, 7813-7818. [CrossRef] [PubMed]

53. Tuerde, D.; Kimura, T.; Miyasaka, T.; Furusawa, K.; Shimozawa, A.; Hasegawa, M.; Ando, K.; Hisanaga, S.-I. Isoform-independent and -dependent phosphorylation of microtubule-associated protein tau in mouse brain during postnatal development. J. Biol. Chem. 2018, 293, 1781-1793. [CrossRef] [PubMed]

54. Yuan, H.; Du, L.; Ge, P.; Wang, X.; Xia, Q. Association of microtubule-associated protein tau gene polymorphisms with the risk of sporadic Alzheimer's disease: a meta-analysis. Int. J. Neurosci. 2018, 128, 577-585. [CrossRef] [PubMed]

55. Hartlage-Rübsamen, M.; Ratz, V.; Zeitschel, U.; Finzel, L.; Machner, L.; Köppen, J.; Schulze, A.; Demuth, H.-U.; von Hörsten, S.; Höfling, C.; et al. Endogenous mouse huntingtin is highly abundant in cranial nerve nuclei, co-aggregates to Abeta plaques and is induced in reactive astrocytes in a transgenic mouse model of Alzheimer's disease. Acta Neuropathol. Commun. 2019, 7, 79. [CrossRef] [PubMed] 
56. Horvath, I.; Weise, C.F.; Andersson, E.K.; Chorell, E.; Sellstedt, M.; Bengtsson, C.; Olofsson, A.; Hultgren, S.J.; Chapman, M.; Wolf-Watz, M.; et al. Mechanisms of protein oligomerization: Inhibitor of functional amyloids templates alpha-synuclein fibrillation. J. Am. Chem. Soc. 2012, 134, 3439-3444. [CrossRef] [PubMed]

57. Nielsen, S.B.; Macchi, F.; Raccosta, S.; Langkilde, A.E.; Giehm, L.; Kyrsting, A.; Svane, A.S.P.; Manno, M.; Christiansen, G.; Nielsen, N.C.; et al. Wildtype and A30P mutant alpha-synuclein form different fibril structures. PLoS ONE 2013, 8, e67713. [CrossRef] [PubMed]

58. Annamalai, K.; Gührs, K.-H.; Koehler, R.; Schmidt, M.; Michel, H.; Loos, C.; Gaffney, P.M.; Sigurdson, C.J.; Hegenbart, U.; Schönland, S.; et al. Polymorphism of amyloid fibrils in vivo. Angew. Chem. Int. Ed. Engl. 2016, 55, 4822-4825. [CrossRef]

59. Lindberg, D.J.; Wranne, M.S.; Gilbert Gatty, M.; Westerlund, F.; Esbjörner, E.K. Steady-state and time-resolved Thioflavin-T fluorescence can report on morphological differences in amyloid fibrils formed by A $\beta(1-40)$ and A $\beta(1-42)$. Biochem. Biophys. Res. Commun. 2015, 458, 418-423. [CrossRef]

60. Jin, S.; Kedia, N.; Illes-Toth, E.; Haralampiev, I.; Prisner, S.; Herrmann, A.; Wanker, E.E.; Bieschke, J. Amyloid- $\beta(1-42)$ aggregation initiates its cellular uptake and cytotoxicity. J. Biol. Chem. 2016, 291, 19590-19606. [CrossRef]

61. Malisauskas, M.; Ostman, J.; Darinskas, A.; Zamotin, V.; Liutkevicius, E.; Lundgren, E.; Morozova-Roche, L.A. Does the cytotoxic effect of transient amyloid oligomers from common equine lysozyme in vitro imply innate amyloid toxicity? J. Biol. Chem. 2005, 280, 6269-6275. [CrossRef]

62. Hoenen, C.; Gustin, A.; Birck, C.; Kirchmeyer, M.; Beaume, N.; Felten, P.; Grandbarbe, L.; Heuschling, P.; Heurtaux, T. Alpha-synuclein proteins promote pro-inflammatory cascades in microglia: Stronger effects of the A53T mutant. PLoS ONE 2016, 11, e0162717. [CrossRef] [PubMed]

63. Lashuel, H.A.; Overk, C.R.; Oueslati, A.; Masliah, E. The many faces of \alpha-synuclein: From structure and toxicity to therapeutic target. Nat. Rev. Neurosci. 2013, 14, 38-48. [CrossRef]

64. Béraud, D.; Hathaway, H.A.; Trecki, J.; Chasovskikh, S.; Johnson, D.A.; Johnson, J.A.; Federoff, H.J.; Shimoji, M.; Mhyre, T.R.; Maguire-Zeiss, K.A. Microglial activation and antioxidant responses induced by the Parkinson's disease protein $\alpha$-synuclein. J. Neuroimmune Pharmacol. 2013, 8, 94-117. [CrossRef] [PubMed]

65. Maniatis, T.; Fritsch, E.F.; Sambrock, J. Molecular Cloning. a Laboratory Manual; Cold Spring Harbor Lab: Cold Spring Harbor, NY, USA, 1984; ISBN 9780879691363.

66. Cabrita, L.D.; Gilis, D.; Robertson, A.L.; Dehouck, Y.; Rooman, M.; Bottomley, S.P. Enhancing the stability and solubility of TEV protease using in silico design. Protein Sci. 2007, 16, 2360-2367. [CrossRef] [PubMed]

67. Schlenzig, D.; Rönicke, R.; Cynis, H.; Ludwig, H.H.; Scheel, E.; Reymann, K.; Saido, T.; Hause, G.; Schilling, S.; Demuth, H.U. N-Terminal pyroglutamate formation of Abeta38 and Abeta40 enforces oligomer formation and potency to disrupt hippocampal long-term potentiation. J. Neurochem. 2012, 121, 774-784. [CrossRef]

68. Spahn, C.; Wermann, M.; Eichentopf, R.; Hause, G.; Schlenzig, D.; Schilling, S. Purification of recombinant $\mathrm{A} \beta(1-42)$ and pGlu-A $\beta(3-42)$ using preparative SDS-PAGE. Electrophoresis 2017, 38, 2042-2049. [CrossRef]

69. Schlenzig, D.; Manhart, S.; Cinar, Y.; Kleinschmidt, M.; Hause, G.; Willbold, D.; Funke, S.A.; Schilling, S.; Demuth, H.U. Pyroglutamate formation influences solubility and amyloidogenicity of amyloid peptides. Biochemistry 2009, 48, 7072-7078. [CrossRef]

70. Hortschansky, P.; Schroeckh, V.; Christopeit, T.; Zandomeneghi, G.; Fändrich, M. The aggregation kinetics of Alzheimer's beta-amyloid peptide is controlled by stochastic nucleation. Protein Sci. 2005, 14, 1753-1759. [CrossRef]

71. Hsiao, K.; Chapman, P.; Nilsen, S.; Eckman, C.; Harigaya, Y.; Younkin, S.; Yang, F.; Cole, G. Correlative memory deficits, Abeta elevation, and amyloid plaques in transgenic mice. Science 1996, 274, 99-102. [CrossRef]

72. Hartlage-Rübsamen, M.; Bluhm, A.; Piechotta, A.; Linnert, M.; Rahfeld, J.-U.; Demuth, H.-U.; Lues, I.; Kuhn, P.-H.; Lichtenthaler, S.F.; Roßner, S.; et al. Immunohistochemical evidence from APP-transgenic mice for glutaminyl cyclase as drug target to diminish pE-Abeta formation. Molecules 2018, 23, 924. [CrossRef]

73. Fujiwara, H.; Hasegawa, M.; Dohmae, N.; Kawashima, A.; Masliah, E.; Goldberg, M.S.; Shen, J.; Takio, K.; Iwatsubo, T. alpha-Synuclein is phosphorylated in synucleinopathy lesions. Nat. Cell Biol. 2002, 4, 160-164. [CrossRef]

74. Gorbatyuk, O.S.; Li, S.; Sullivan, L.F.; Chen, W.; Kondrikova, G.; Manfredsson, F.P.; Mandel, R.J.; Muzyczka, N. The phosphorylation state of Ser-129 in human alpha-synuclein determines neurodegeneration in a rat model of Parkinson disease. Proc. Natl. Acad. Sci. USA 2008, 105, 763-768. [CrossRef] 
75. Doppler, K.; Jentschke, H.-M.; Schulmeyer, L.; Vadasz, D.; Janzen, A.; Luster, M.; Höffken, H.; Mayer, G.; Brumberg, J.; Booij, J.; et al. Dermal phospho-alpha-synuclein deposits confirm REM sleep behaviour disorder as prodromal Parkinson's disease. Acta Neuropathol. 2017, 133, 535-545. [CrossRef]

76. Becker, A.; Eichentopf, R.; Sedlmeier, R.; Waniek, A.; Cynis, H.; Koch, B.; Stephan, A.; Bäuscher, C.; Kohlmann, S.; Hoffmann, T.; et al. IsoQC (QPCTL) knock-out mice suggest differential substrate conversion by glutaminyl cyclase isoenzymes. Biol. Chem. 2016, 397, 45-55. [CrossRef]

Sample Availability: Samples of the compounds are available from the authors.

(C) 2020 by the authors. Licensee MDPI, Basel, Switzerland. This article is an open access article distributed under the terms and conditions of the Creative Commons Attribution (CC BY) license (http://creativecommons.org/licenses/by/4.0/). 